\title{
INFLUENCE OF MATHEMATICAL COMPOSITION FOR PUBLIC SPACE IN THE EXPERIENCE OF USERS: ALEJANDRO ZOHN'S WORK
}

\author{
ALFRED ESTELLER AGUSTII ${ }^{1}$, ISAMAR A. HERRERA PIÑUELAS ${ }^{1}$ \\ \& ADOLFO VIGIL DE INSAUSTI ${ }^{2}$ \\ ${ }^{1}$ Universidad del Valle de Atemajac, México \\ ${ }^{2}$ Universitat Politècnica de València, Spain
}

\begin{abstract}
Alejandro Zohn's work in Guadalajara (1930-2000) is analysed in order to recognize its contributions, influences and value in spatial, functional, aesthetic and spiritual experience of the users. The main features of his work are based on arithmetic visions and analytical perspective and is focused on the research for compositions through the use of geometric volumes, usually concrete. Generated through mathematics in a process linked to fractal growth, an issue that from pragmatism and composition become strong characteristics associated with biophilia, aesthetics and well-being, turning the envelope into a complex map of visual codes. Hence starts the extensive use of the hyperbolic paraboloid, following the path of Eduardo Torroja and Félix Candela, giving it a masterful expressive depth using contrasts along with traditional materials and natural elements. It is this duality that brings the spatial aesthetic closer to the user's appreciation by combining forms that refer us to the anthropic; intellectual and ethereal, with natural elements that link us to a more instinctive and biological level. Systematic observation methods and user surveys allows us to obtain conclusions of the analytical exercise from a perspective of perception of the public space, linked to a contrast of results of homologous exercises in the area of neurourbanism and with a deductive logical method that allows to obtain particular conclusions where links and logics are established associated with architectural volumetric.
\end{abstract}

Keywords: nature-related forms, fractal growth, neurourbanism, functional structures, shadow, monumentalism, hyperbolic paraboloids, geometry.

\section{INTRODUCTION}

The figure of Alejandro Zohn as an architect and engineer was very fruitful in the last decades of the last century in the state of Mexico. Much of his works are characterized by the predominant use of pure geometry, giving their concepts a marked sculptural characteristic and aesthetic, sometimes even brushing the elastic limits of the materials themselves. At the same time, the geometric understanding used from the sacred architecture through the golden ratio and subsequently the Fibonacci section, since a close link between the geometry and the origin of the universe is recognized of historical interest. This research focuses, in one hand, on the recognition of the figure of Alejandro Zohn, through a methodical analysis of some of his works, that allow to know the functions as well as the geometric design criteria of a series of relevant constructions developed inside the public space, but also, in the other hand, is completed through the measurement of biophilia, the acceptance that these constructions linked to nature currently maintain in users through comparative visual surveys despite their unfortunate state of conservation of some of them, in order to emphasize the purity and sensitive of these structures, the importance of the work of Zohn and the need of recovery of these architectural landmarks. 


\section{PROFESSIONAL DEVELOPMENT AND INFLUENCES}

\subsection{School life and creative environment}

Alejandro Zohn Rosenthal [1] born in Austria on 8 August 1930, his mother chemical and father accountant, developed a childhood and adolescence surrounded by mathematics and science, began his professional academic life studying civil engineering career, but, at time when the architecture degree was opened in the same university, he decided to study both careers at the same time, ending civil engineering degree on 21 May 1955 [1] and the architecture degree, according to the yearbook of the University of Guadalajara [2, p. 91] in 1959. His training in both lines was decisive for the formal expression of his works. The professors instructed him in addition having a link to architecture from the development in other areas related to the arts. This settled a pattern in a decisive influence on the logicalengineering thinking of Zohn. Dr Marian Goeritz [2, p. 84] her married name, real Marianne Gast, photographer and writer [3], architect Jaime Castiello Camarena [2, p. 84] influenced by the modern movement, architect Ignacio Díaz Morales [2, p. 84] precursor of regionalist architecture [4], Professor Domingo Lobato [2, p. 84], composer, organist and teacher [5], Ing. Francisco González Rojo [2, p. 84] writer, film scriptwriter and ethnologist [6], Architect Eric Coufal [2, p. 84] work inspired by the Mexican tradition, specifically in crafts, Dr Manuel Herrero Morales [2, p. 84] mathematician professor from Spain [7], Mr José Arriola Adame [2, p. 84] great promoter of culture in his hometown. Every Sunday he summoned his young disciples and his intellectual friends in the magnificent library of his private home, including Canon José Ruiz Medrano, politician Efraín González Luna, architects Luis Barragán and Ignacio Díaz Morales, internationalist Antonio Gómez Robledo, the writer Agustín Yáñez, among others, to delight in music and discuss literature and philosophy [8] and Dr Mathias Goeritz [2, p. 84] architect, sculptor, painter, poet and art historian [9], this one, played a key role from the beginning of Zohn's training, being the reason why he decided to enter the architectural career.

\subsection{Professional forming influences}

"I kept studying engineering. and at that time a series of people came to what was the school of architecture, among them Mathias Goeritz. I met him casually on one of the visits, and since I had some time between engineering classes, I got into some of his classes and I liked them a lot. I think it was because of Mathias that I got into architecture" [10, p. 120].

Mathias, in his trajectory of his sculptural works, loaded with formal power and with strong constructive solutions; mostly in particular, the influence that Alejandro could have endowed during his years of study and after that. Zohn himself recounts it during his interview with Fernando González [10, p. 153] "Well, there is one thing, I don't know how relevant, but that has influenced me in certain areas. In the other Mathias classes (...) the way he made us know and perceive these artists, I was much more alive than the other teaching techniques, in which one learns all people and all productions, and after a while you have a huge confused profusion of absolutely incoherent ideas".

Although Ignacio Diaz Morales and Mathias Goeritz had an impact on Alejandro's learning, Félix Candela should also be mentioned, although he was not a full-time professor at the University of Guadalajara he participated as a guest teacher [11]. Candela's shell-like concrete structural techniques with the use of paraboloids were also referents during Alejandro's formation, of course also the work that Felix was already doing in Mexico since his exile after the Spanish civil war [12]. 
Alejandro Zohn, achieved a professional character beyond a style, an essence endowed by his teachers who, transcending the architectural message, postulated what art expressions can transform in the creator's mind, a design process. Although Alejandro specialized in the geometric construction line, which is binding on his training as a civil engineer, the paraboloids was not the only line of reflection in which he maintained himself, the metabolism of the cities also formed a large part of his professional analysis, as he mentions in one of his books [13], "we must take care of the analogies that condition absurd conclusions (for example, that cities, like all living organisms, are born, mature and die)".

\subsection{The mathematical influence in his work}

The influence that Alejandro Zohn could have during his years of study and how relevant it turned out to have studied two binding careers for a design process in Mexico formally defined the type of structures that would work throughout his career, same ways that Felix Candela worked. Hyperbolic paraboloids in their mathematical hardness are figures that contrast themselves in various aspects; they also manage to be soft and noble shapes in sight with the generation of curves resulting from straight lines, they are structurally super resistant thus achieving heights and clearings of great proportions. Attaining to bring an imposing sensation on the viewer, but on a sensitive logical nature with conformation through organic forms.

In contradistinction to Candela, Alejandro respected the paraboloids in their total mathematical openness without generating curves or smoothing the edges. Somehow, taking refuge in mathematics brought certainty to his work, all the works were executed and supervised by him, transforming it into a highly dominated technique. In a current interview with her daughter Laura Zohn [14] she expressed an answer perhaps much simpler regarding the use of forms for her father: I asked him: "Dad, why do you never make curves?" And he told me: "Because I do not feel them. The triangles and things that ended in peaks were nicer to him".

\subsection{Selected works}

The works to analyze in the present investigation have been selected for sharing the characteristic related to their function as a roof, although, each one fulfills another architectural function and user experience. The three structures also share the same year of construction, 1959 [15] and are located in a range of less than $5 \mathrm{~km}$.

1. Acoustic shell in Agua Azul Park in Guadalajara, Jalisco.

2. Main access in López Mateos sports complex in Guadalajara, Jalisco.

3. Double bleachers in López Mateos sports complex in Guadalajara, Jalisco.
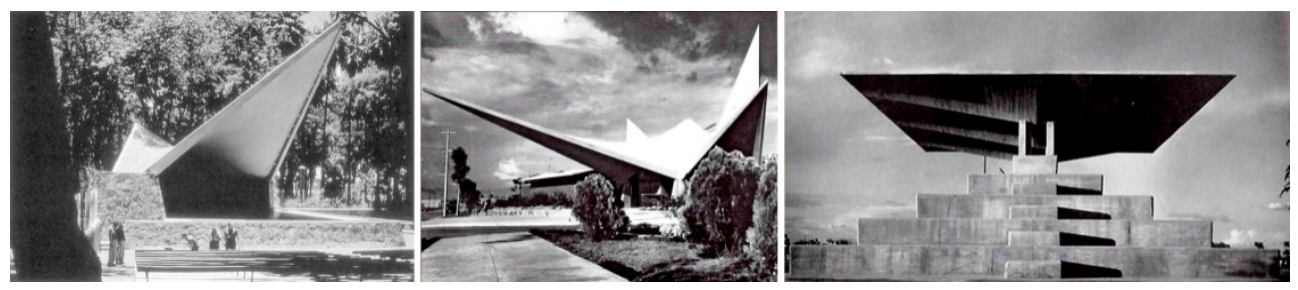

Figure 1: Works in order of analysis. (Source: Zohn's archive.) 


\section{APPROACH TO THE EVALUATION OF THE RELATIONSHIP BETWEEN GEOMETRY, NATURE AND PUBLIC SPACE}

It is already well studied that mathematics and geometry have a direct relationship with forms in nature, the interesting issue to discuss in present research is the relation between them and the perception of space. In order to do that, several concepts must be taken into account.

Geometric analysis based on a mathematical understanding has been remotely used since ancient times in sacred construction; spaces determined to accommodate the prevailing god, it was sought that the structuring of those buildings refer to sacred conceptualizations, taking geometric forms as [16] a metaphor for the Ordination of the Universe, from the word geometry as a measure of the earth, to the strong connections of the symbols in the runic script, Uruk to the Babylonian, engraved on stones in various parts of the world, sacred megaliths such as Stonehenge and Nabta and following the architectural expressions of temples and pyramids along the globe. All of them, with a shared feature related to the search for geometry and its relationship with the cosmos as its basic design foundation. Multiple current studies focus on finding geometric and mathematical relationships in buildings, although mostly in those of sacred origin, mainly cathedrals and churches, or buildings of a historical nature with techniques including digital simulation [17]. For specific documentation and of preservation for the quality of the buildings. Although, consistently prevailing due to its ease of approach to mathematical and geometric understanding as well as the possibilities of analysis of the architectural object in question with respect to structure, beauty and functionality, it is still the method of proportion and composition by proportion of area or section of Fibonacci [18].

\subsection{Biophilia}

The concept of biophilia, although recently attributed to Edward Osborne Wilson, was first used by psychologist and philosopher Erich Fromm: The words biophilia and necrophilia are unattractive, they do not invite. They bring to mind diseases such as hemophilia and have the aura of heavy claims of scientific authority. They are estimated alienated words. Biophilia means, of course, love of life [19]. Biophilia has come to explain the relationships of perception beyond the physical but also to the cognitive of empathy or approach that we feel towards the elements or related to nature, it is this evolutionary love for the environment that has led to conditions of our life to which we show a certain attachment or affinity. Schultz [20] says many of the philosophical and sociological theories about human-environment relationships use the term connectedness to describe the extent to which individuals believe that they are part of the natural world. Although it is often used in a broader context, the core of a connection with nature is cognitive. Connectedness refers to the extent to which an individual includes nature within his/her cognitive representation of self.

\subsection{Geometric patterns related to nature and the human being}

To the human eye, the mathematical forms found in nature, such as geometries, symmetries or fractality, are proven satisfactory and in some cases even reassuring, what leads to current trends where the linkage of open natural spaces is increasingly used for treatment of stress and anxiety. Blue Brain Project [21] who oversees to build biologically detailed digital reconstructions and simulations of the rodent, and ultimately the human brain, has discovered in his latest research how brain synapse patterns have organizational trends in geometric shape, evidencing polyhedral forms when making decisions. Numbers and mathematics from the micro to the macrocosm surround what we understand as material space and therefore 
conditions us or at least influence as aspects with which the human being must feel comfortable. Jung explain [22] Perception (sensory perception) shows us that something exists; thoughts tells us what it is; feeling tells us whether it is pleasant or not; and intuition tells us where it comes from and where it is going. This way the perception that works through the senses, in the simplified or extended version of Steiner are the channels with which it connects with the outside world. Attending to this Alejandro Zohn's works, they belong to Mexican modern movement from mid twentieth century, in which proportions and mathematical ratios were the core of the design process. Among them the natural Phi proportion, or Golden triangle was very appreciated in order to create growing systems and for the introduction of regulated curves into usually rectangular shaped designs.

\subsection{Perception of public space}

Public space is part of a complex artificial environment and is shared by a series of elements that humanity has created, as most part of them are built elements which form a parallel environment to the natural world. Depending on the location and conditions in those that are found and as it was developed it will be more or less linked to the most recognized natural elements such as flora and fauna. These elements with the capacity to be inserted in the constructed space also acquire symbolisms and interactions in the consciousness and subconscious of the users, what Kevin Lynch calls "legibility" of the urban landscape [23], what is related with the love for nature or rather, biophilia, presented before. But, in addition, as explained in Section 3.2, mathematical conditions found not only in nature but in everything that surrounds us will be acting through our subconscious as a message of pleasure. Alejandro Zohn himself refers to the close relationship with the built environment [24] Architecture is something whose presence is virtually inevitable. We cannot stop seeing it, of living it, of feeling its influence. For those of us who live in cities, architecture is more present than nature itself. Everything we observe is causing an effect on perception and the relationships that invisibly connect to what in our paradigms has been predefined as known forms, returning a feedback between geometry and nature. Alike French painter Cezanne said: You must learn to look at nature in the form of cones, cylinders, spheres and pyramids [25], but it is that, in turn, geometric shapes transport elements in nature.

\section{CRITICISM AND ANALYSIS OF THE PERCEPTION OF PUBLIC SPACE}

\subsection{Systematic observation methodology}

The analysis of the Alejandro Zohn works is developed based on three comparative parameters that are applied to the three works analyzed to obtain a significant contrast in relation to observation; form and function, geometric aesthetics and sensory experience. In addition, the results of an anonymous group are shown about the perception in relation to the shapes and geometry shown in the test was carried out by means of an oculocentric survey.

\subsection{Geometric and function analysis}

\subsubsection{Acoustic shell in Agua Azul Park in Guadalajara, Jalisco}

Form and function: Spatially, the definition of the shell is solved by a hyperbolic paraboloid in equilibrium on a pair of stone boxes who work as foundation and balance the weight of the cantilever towards the audience, providing shadow and a perfect soundwave diffusion. In fact, the configuration of the form in this case, comparing with the other two studied elements, is the one that has the greatest dependence on the function to be developed by the 
element, since the definition of the curve, height, angle and even surface finishes were crucial in order to ensure optimum operation of the shell as a sound distributor element towards the stands, in this way the focality of the function is perfectly combined with the volumetric presence and image of the element.

Geometric aesthetics: Among the three elements analyzed, the shell is geometrically the intermediate element according to its geometrical composition, as Zohn disposes a balanced element, practically a square slightly bent on front half. Through which the natural force of gravity is clearly confronted by Zohn using the distribution of the load in the form of a catenary, as it worked splendidly and is observed in the work of Antoni Gaudí, throughout the straight lines of the parabolic hyperboloid. Extending to the public, completing with the stands and presenting itself as a visual focus of the whole set. As can be seen in Fig. 2, the Fibonacci rectangle used in two scales in order to proportion the bases and the paraboloid and the height of the front wave of the paraboloid, and how do they work in order to achieve the structural balance, on the opposite side, in Fig. 3 the height of the triangle is defined again by the golden rectangle, in this case the junction of two of them are equal to the wide of the bigger one which determines the height of the front side.
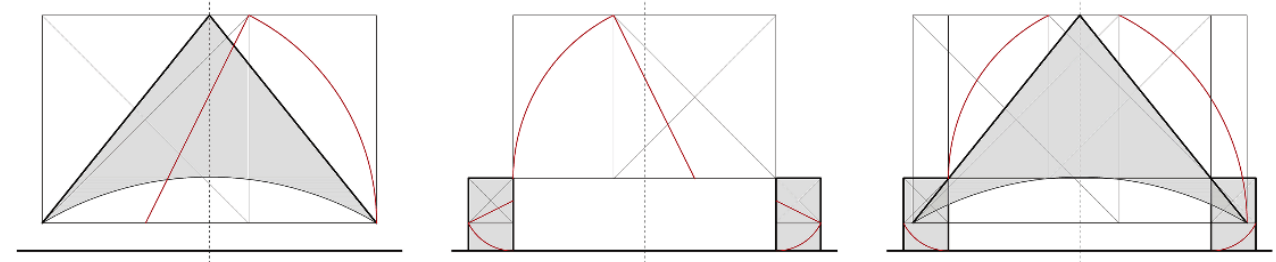

Figure 2: Acoustic shell, frontal view, geometric analysis.
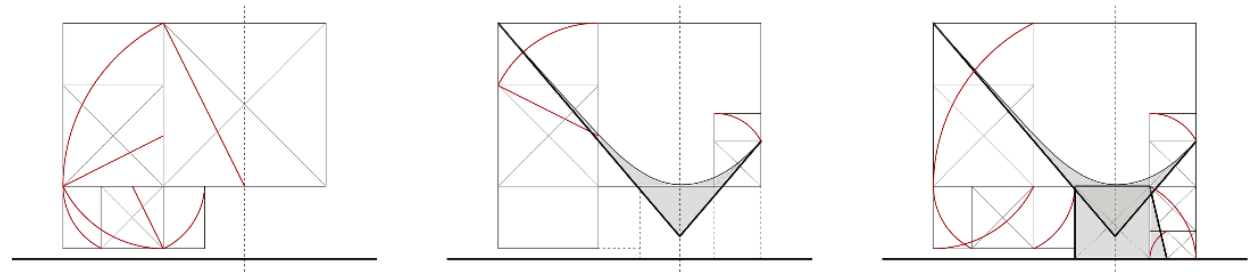

Figure 3: Acoustic shell, side view, geometric analysis.

4.2.2 Main access in López Mateos sports complex in Guadalajara, Jalisco

Form and function: With this complex element Zohn solves the entrance function adding the need of offering shelter from the severe sunlight or torrential rains, with an element that seeks greater height and length across the direction of the fence in response to the urban scale. As the entrance is placed in one of the great avenues of the city. In addition, the composition of the form represents the interior-exterior duality of entrances, offering magnitude outwards through the element that colonizes the street, while in the interior by means of the elevation of the counterposed element, it offers a confinement to the interior space, dominating and changing the perception of scale through the transition from outside to the complex. 
Geometric aesthetics: Geometrically it is the most complex element of the three analyzed, with four L-shaped supports forms an exact square that includes the function of the entrance hall. On these four bases, as a star, four open triangles are raised symmetrically respect to the longitudinal axis at its base as can be seen in Fig. 4, the side corresponding to the central square is one of the two main elements for composition, determining the length of back wing with Fibonacci's proportion, while the other golden square delimitates the length in cantilever of outer wing.

Same proportions are used to determine the form of the cross-shaped star generated from the main centre. Attending to heights, Fig. 5 shows how, on the axis perpendicular to the entrance, one of the major triangles, the interior, rises colossally with the objective of achieving the counterweight necessary to support its opposite that extends courageous to the street. The dimensions taken to ensure this structural and compositional balance are also defined by following the mathematical rules used in floorplan, using the same big rectangle dimensions to fix the starting height of the form and top points of crossed wings and Fibonacci's evolution for the other top point heights of the main wings.
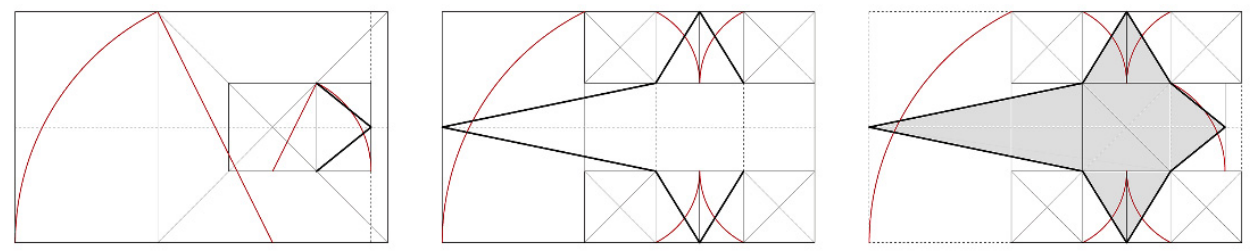

Figure 4: Access, floorplan, geometric analysis.
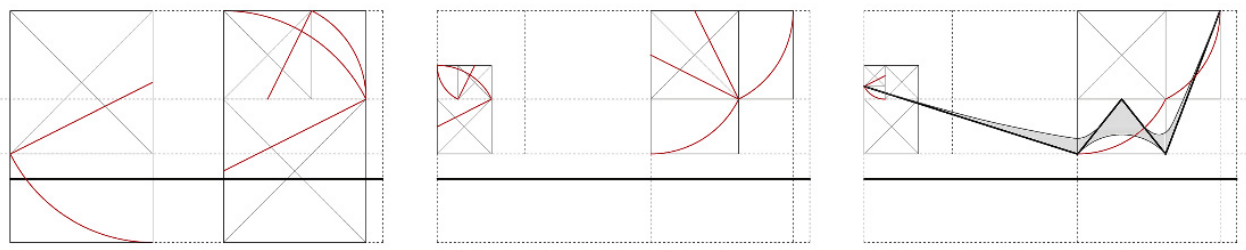

Figure 5: Access, sideview, geometric analysis.

\subsubsection{Double bleachers in López Mateos sports complex in Guadalajara, Jalisco}

Form and function: In this case, the function becomes the main starting element for the composition, since the stands are arranged as an elongated pyramid on one of the axes, with a necessarily regular geometry in order to guarantee their functionality. That is the reason why Zohn chooses to raise a much more rigid element for the protection of the public, abording more static language, disposing three pair of squared columns on the top of the pyramid from which, as a kind of umbrellas, grow a rectangular shape in the four directions, two longer and two shorter, the ones that link the rectangle with its partner by one of the longer sides, leaving the support in the centre of the rectangle, granting the roof a slight curvature that gives it lightness and helps in the correct distribution of the loads towards the shaft. 
Geometric aesthetics: Unlike the other elements analysed the mathematical ratio used in this case only takes into account the golden rectangle when analysing the section, as in Fig. 6 is presented the general dimensions of the steps and cover respect this ratio, as well as the proportion of the seats and stairs. On the other side, the solution of the cover in roof plan exposes a simpler mathematical system, where each one of the three parts, hold by a pair of squared pillars, has a 2:1 ratio, which repeats three times, so the whole cover ratio ends up being 3:2. For the position of the columns the basic square used can be located in the crossing to obtain the relation between surfaces, where the pillars are located in the exact center as an umbrella.
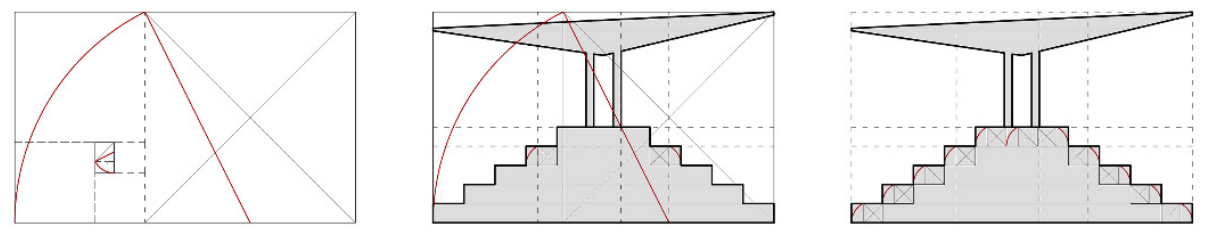

Figure 6: Bleachers, cross section, geometric analysis.

\subsubsection{Public perception}

In the main purpose of understanding how proportions and shapes related with nature are appreciated by general public the present study couldn't be limited to the analyse of mathematical the elements, staying in theoretical analytical field. However, the need of interpreting how users perceive places of this urban scale became fundamental in order to establish the possible impact of different features of these works in users, as well as pondering the impact they have generated in the city of Guadalajara along fifty years, directed us to generate a practical field where analytical part fuses with on-field work, what gives this study a higher approach to a contemporary investigation.

In order to evidence how the architectural shapes of the structures remain valid in the eyes of the citizen, accompanying the geometric understanding of the mapping performed, a survey was conducted, answered by 117 people, neighbours and users of the area were examples and photographs are located, with the objective of knowing if the biophilia associated with mathematics is really pragmatic for the eye and the feeling of pleasure. Following criteria of neutrality and scientific research, including different profile of surveyors attending to age, sex, education, occupation and relation with the urban elements. Establishing a population around the two parks where the urban elements selected are of 41,455 people, 117 surveys were done, higher than the 110 needed in order to fulfil a $95 \%$ trust with a $15 \%$ margin of error. In the definition of the survey, one photograph of each of the selected Zohn's works where presented to surveyed citizens with other three photographs of other elements with the same function in the city of Guadalajara if possible, although due to the lack of possibilities gaps needed to be filled were with the best criteria according to economic investment, year of construction, size, etc. Following neutrality criterion, all photographs were in grayscale with the objective of focusing the answers on the observation of shapes. Every picture is treated in the same way, balancing brightness and contrast between them, avoiding any artistical intention, or other remarkable stimulus, taken a regular day by nonprofessional photographers. This way it's prevented any possible interferences that could alter the motivation of the answers and caring the most about the clearest appreciation of profiles or edges of each of the structures shown. 


\section{RESULTS}

Interpretation of the geometrical analyse of Alejandro Zohn's selected works deserves a brief attendance in order to observe the important commitment with mathematics, proportions, and geometric development impressed into his designs, understanding the right structural behaviour is linked to respect of natural forces and laws, which can be seen in mathematics and rules of nature. And how knowing and enforcing them in architecture through related geometry, shapes, ratios can bring designs to excellence like the three works studied achieved in their fields, where Fibonacci's rectangle is constantly present helping to develop the most accurate and balanced solution.

On the other branch of the study, the result of the survey showed Zohn's works are nowadays still most appreciated by the public, as they resulted the most voted in all cases, splitting recognitions of their forms with other cases exposed in, but on the part of the respondents because in all three questions it is Zohn's work that was the most voted.

In all charts in Fig. 7 Alejandro Zohn works are coloured blue, and shows, for example, linked with the question of which shape seems more attractive to surveyed people, Alejandro Zohn's acoustic design is the preferred with a $33.3 \%$ but close to other two options. It can be interpreted as most of the shells have designs that can be appreciated by general public, as those are spaces with important inversions and very enjoyable for the visitors. Nevertheless is important to notice than comparing with the next two options, Zohn's construction is by far the one in worst maintenance condition, what must lead to a thought about the care of local architecture referents in our cities.

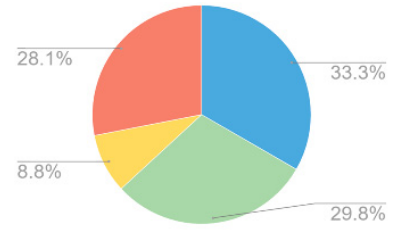

Question 1. Acoustic cell preferences.

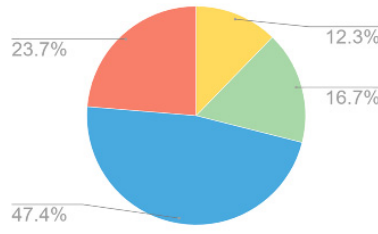

Question 2. Park access preferences.

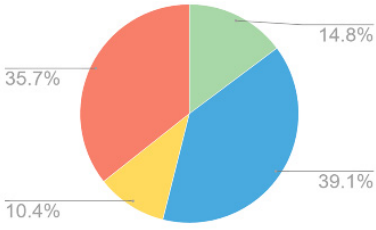

Question 3. Bleachers preferences.

Figure 7: Survey results.

For the next element studied, the impressiveness of the form explained of Zohn's design for Sport Complex' main access in López Mateos is shown with the biggest difference in voting, as other entrances for parks in the city have more sober and rectangular designs, what differences it notoriously from the others, even being in one of the least glamourous areas of the city, while in other photographs were entrances of more appreciated, more cared and visited parks, located in wealthier neighbourhoods.

By last, bleachers question is almost a draw with next appreciated photograph, in this case the simplicity of the design in Zohn's proposal compete with other more grandiloquent proposals, both in size and economic investment.

\section{CONCLUSIONS}

Formal design based on the modern movement is evident in Alejandro Zohn's work, being the reflection of the "Escuela Tapatía" that was beginning to bloom, strengthen its totally mathematical and brutalist character. The geometries in gentle play with the formality of nature provides Zohn's work a character that after 60 years of built remains attractive and mesmerizing for user due to their majestic expression. The architectural work remains up to 
date, but not the care of this important urban pieces, as they show lack of maintenance and demand for current policies, although the auditorium was partially restored few years ago, later works have not been followed, the bleachers are quite well preserved over time because of its simplicity and original design, and the entrance, maybe the most important, is in an unfortunate state of deterioration, but expecting to its quickly recovery according to the Ministry of Infrastructure and Public Works [26].

The fact Alejandro Zohn embodied the fusion between architecture and construction engineering due to his dual formation led him to solve the problem of space from an integral understanding, a holistic conception of the envelope, the ceiling, defined by Ching as "The roof plane can be conveniently treated in order to determine and articulate volumes of an interior space. To modify the proportion of an area, to highlight a circulation or to allow natural light to enter, it is possible to descend or raise the ceiling plane. The shape, color, texture and pattern of the ceiling can also be treated, in order to improve the acoustic characteristics of a space, or to provide a specific directional nature or orientation" [27]. It was the transformation point for Zohn's work, because the ceiling is transformed into something more than that in which functionality reduces it, for Alejandro the ceiling became an opportunity to transform the visual, sensory and constructive perception of public space, and beyond are now elements that continue to educate and transform the conception of spaces and this gives architecture immense educational importance. It is possible to learn the taste of appreciating the beautiful and hating the ugly; to enjoy the harmonic and to reject chaos [24]. As global reflection, the results of the research could be contrasted with the validity of other structures that currently remain highly appreciated by general public because of their expressive character; such as those of Félix Candela, Oscar Niemeyer and others, where the structure is extremely powerful, attractive and with a direct relationship to the skeletal forms of animals or curvilinear relationships of vegetation.

\section{REFERENCES}

[1] Universidad de Guadalajara, Enciclopedia histórica y biográfica de la Universidad de Guadalajara. $\quad$ http://enciclopedia.udg.mx/biografias/zohn-rosenthal-alejandro. Accessed on: 19 Jan. 2020.

[2] Universidad de Guadalajara, Facultad de arquitectura 1948-1983, Universidad de Guadalajara, Facultad de Guadalajara: Guadalajara, Jalisco, Mexico, 1983.

[3] Librería Gil, Premio Nacional Librería Cultural, Presentación de Marianne Gast (1910-1958) en el archivo Lafuente. www.libreriagil.com/marianne-gast-1910-1958en-el-archivo-lafuente/. Accessed on: 25 Jan. 2020.

[4] El informador, Nostalgia regionalista. www.informador.mx/Suplementos/Nostalgiaregionalista-20121027-0022.html. Accessed on: 25 Jan. 2020.

[5] Cruz, G., Instituto de Investigaciones históricas, políticas, económicas y sociales. https://institutohistorico.org/domingo-lobato-banales/. Accessed on: 25 Jan. 2020.

[6] Ortiz, J., Lifeder. www.lifeder.com/francisco-rojas-gonzalez/. Accessed on: 25 Jan. 2020.

[7] Kasis, A., Monografías de arquitectos del siglo XX, vol. 1, Alejandro Zohn. Ingeniería, arquitectura y planeación, Pandora: Guadalajara, Jalisco, México, p. 148, 2004.

[8] Universidad de Guadalajara, Enciclopedia histórica y biográfica de la Universidad de Guadalajara. http://enciclopedia.udg.mx/articulos/arriola-adame-jose. Accessed on: 25 Jan. 2020.

[9] LJA, www.lja.mx/2015/04/solo-si-emociona-la-arquitectura-puede-considerarse-unarte-mathias-goeritz/. Accessed on: 25 Jan. 2020. 
[10] González, F., Mathias Goeritz en Guadalajara, Universidad de Guadalajara: Guadalajara, Jalisco, México, 1991.

[11] HANSKABSCH, Parroquia de San Jerónimo en Zapopan. http://hanskabsch.blogspot.com/2010/01/parroquia-de-san-jeronimo-enzapopan.html. Accessed on: 1 Feb. 2020.

[12] Acción Cultural Española, Felix Candela (eBook), AC/E. www.accioncultural.es/es/publicaciones/felix-candela. Accessed on: 1 Feb. 2020.

[13] Consejo Nacional para la Cultura y las Artes, Alejandro Zohn: Arquitectura y reflexiones, AGATA: Guadalajara, Jalisco, México, p. 161, 1999.

[14] El informador, Alejandro Zohn, la geometría de la memoria, 9 de agosto de 2015. www.informador.mx/Suplementos/Alejandro-Zohn-la-geometria-de-la-memoria20150809-0158.html. Accessed on: 1 Feb. 2020.

[15] Rábago, J., Monografias de arquitectos del siglo XX, vol. 20, Alejandro Zohn. Ingeniería, arquitectura y planeación, Pandora: Guadalajara, Jalisco, México, pp. 4959, 2011.

[16] Castro, O., La experiencia cultural de lo sagrado a través de la geometría. De los albores de la humanidad hasta la aritmosofía de Pitágoras. Pensamiento: Revista de Investigación E información Filosófica, 63(238), pp. 743-775. https://razonyfe.org/index.php/pensamiento/article/view/4560.

[17] Alvarez, I. et.al., Diferentes propuestas para la representación geométrica de edificios históricos. Arqueología de la arquitectura, 2, pp. 9-12, 2013. https://addi.ehu.es/bitstream/handle/10810/8509/ALVAREZ\%20GONZALEZ.pdf?se quence $=1 \&$ isAllowed $=\mathrm{y}$.

[18] Kimberly, E., Geometry of Design: Studies in Proportion and Composition, Gustavo Gili: Barcelona, 2014.

[19] Eckardt, M., Fromm y su concepto de biofilia, Erich Fromm Documente Center, p. 1, 2006. https://opus4.kobv.de/opus4-Fromm/files/8451/Eckardt_Horney_M_2006.pdf. Accessed on: 18 Jan. 2020.

[20] Schultz, P., Inclusion with Nature: The Psychology Of Human-Nature Relations, p. 67, 2002. DOI: 10.1007/978-1-4615-0995-0_4.

[21] EPFL, Blue Brain Project. www.epfl.ch/research/domains/bluebrain/. Accessed on: 1 Feb. 2020.

[22] Collignon-DeAlba, E.G., La naturaleza llama. Urbanistas en búsqueda de la recuperación del primer espacio público, p. 26, 2016. http://hdl.handle.net/11117/4254. Accessed on: 18 Jan. 2020.

[23] Lynch, K., La imagen de la ciudad, Gustavo Gili: Barcelona, p. 11, 1998.

[24] Consejo Nacional para la Cultura y las Artes, Alejandro Zohn: Arquitectura y reflexiones, AGATA: Guadalajara, Jalisco, México, 1999.

[25] Monsteiro, J., El'hypar'está de luto. Arquitectura Viva, 58, p. 116, 1998. http://oa.upm.es/53897/1/1998_hypar_JM.pdf. Accessed on: 1 Feb. 2020.

[26] SIOP, La unidad deportiva López Mateos será renovada, Gobierno del estado de Jalisco. https://siop.jalisco.gob.mx/prensa/noticia/2018. Accessed on: 8 Feb. 2020.

[27] Ching, F., Forma, espacio y órden, Gustavo Gili: Barcelona, p. 118, 2006. 